\title{
Deletion of the Short Arm of Chromosome 1 (1p) Associated Meningioma
}

National Cancer Institute

\section{Source}

National Cancer Institute. Deletion of the Short Arm of Chromosome 1 (1p) Associated Meningioma. NCI Thesaurus. Code C5294.

A mening ioma that is associated with deletion of chromosomal arm $1 \mathrm{p}$. 